\title{
A Novel Approach to Extended Release Clopidogrel: Differentially Coated Mini-Tablets Filled In Hard Gelatin Capsules
}

\author{
Raja Subburayalu ${ }^{1}$, Dr. Janakiraman Kunchithapatham ${ }^{1}$, Dr. Ramkumar \\ Pillappan ${ }^{2}$, Devi.T ${ }^{3}$ \\ Department Of Pharmacy, Annamalai University, Annamalai Nagar, Chidambaram, Tamil Nadu, India, \\ Orchid Chemicals \& Pharmaceuticals Ltd., SIPCOT Industrial Park, Irungattukottai, Sriperumbudur 602 105, \\ Tamil Nadu, India, ${ }^{3}$ Jaya College Of Pharmacy, Thirunindravur, Chennai, Tamil Nadu, India.
}

\begin{abstract}
The main objective of the present study is to formulate an extended release formulation of clopidogrel bisulphate into mini-tablets coated with a combination of $\mathrm{pH}$ dependent polymer, $\mathrm{pH}$ independent polymer and pore former. Clopidogrel is extensively absorbed and 50\% of drug is eliminated in urine in unchanged form. To improve the bioavailability of clopidogrel, the extended release formulation was formulated with an in-situ solubility enhancer, and barrier coated with moisture protective layer. The barrier coated minitablets are coated with the combination of $\mathrm{pH}$ dependant polymer (Hypromellose phthalate HP 50), pH independent polymer (Ethyl cellulose 7cps) and pore former (Hypromellose 5cps) at different ratio, with a weight build up of $10 \% \mathrm{w} / \mathrm{w}$. In-vitro dissolution was studied in $\mathrm{pH} 1.2 \mathrm{HCl}$ for 1 hour, followed by $\mathrm{pH} 6.5$ phosphate buffer for $11 \mathrm{hrs,} \mathrm{using} \mathrm{USP} \mathrm{dissolution} \mathrm{test} \mathrm{apparatus} 1$ at 100 RPM. The formulation (F37), coated with the ratio of 60:25:15 (Ethocel 7cps: Hypromellose phthalate 50: Hypromellose 5cps), shown the better release of 32\% in acid for $1 \mathrm{hr}$, to achieve the loading dose, and the extent of $100 \%$ release at $12 \mathrm{hr}$, in $\mathrm{pH} 6.5$ phosphate buffer. Zero-order, first-order, Higuchi, Hixson-Crowell and Korsmeyer peppas models were used to estimate the kinetics of drug release. Drug release kinetics indicated that the drug release was best explained by Higuchi's equation, as these plots showed the highest linearity $\left(R^{2}=0.9902\right)$ indicating the release of drug from matrix as a square root of time dependent process.
\end{abstract}

KEYWORDS: Dissolution, Clopidogrel, extended release mini-tablets, kinetic modeling.

\section{INTRODUCTION}

Clopidogrel, an inhibitor of platelet aggregation, selectively inhibits the binding of adenosine diphosphate (ADP) to its platelet receptor and the subsequent ADP-mediated activation of the glycoprotein GPIIb/IIIa complex, thereby inhibiting platelet aggregation. Clopidogrel bisulfate is a white to off-white powder. It is practically insoluble in water at neutral $\mathrm{pH}$ but freely soluble at $\mathrm{pH} 1.0^{[1]}$. Orally Clopidogrel bisulfate has a short elimination half-life (7-8 hrs.). Clopidogrel undergoes hepatic first pass metabolism and low oral bioavailability $(50 \%) .{ }^{[2]}$ The term Modified release drug product is used to describe products that alter the timing and/ or the rate of release of the drug substance. Whereas the Extended release dosage forms allows at least a two fold reduction in dosage frequency as compared to that drug presented as an immediate release form. Extended release dosage forms are formulated in such manner as to make the contained drug available over an extended period of time following administration. ${ }^{[3]}$.Modified release formulation of clopidogrel extended release tablets are having better bioavailability and more platelet aggregation effect in comparison to conventional release tablets ${ }^{[4]}$ Multiparticulate (MP) modified release drug delivery systems have several performance advantages vs. single unit dosage forms. After ingestion, MP units are released from the capsule in stomach, predictably transit to the small intestine and spread along the gastro intestinal tract resulting in a consistent drug release with a reduced risk of local irritation. ${ }^{[5]}$

Oral controlled release drug delivery systems can be classified in two broad groups: single unit dosage forms (SUDFs), such as tablets or capsules, and multiple unit dosage forms(MUDFs), such as granules, plelets or mini-tablets. MUDFs, several min-tablets can be either filled into hard capsules or compacted into bigger tablets that, after disintegration, relase these sub units as multiple dosage forms (figure-1) ${ }^{[6]}$ 
(a)

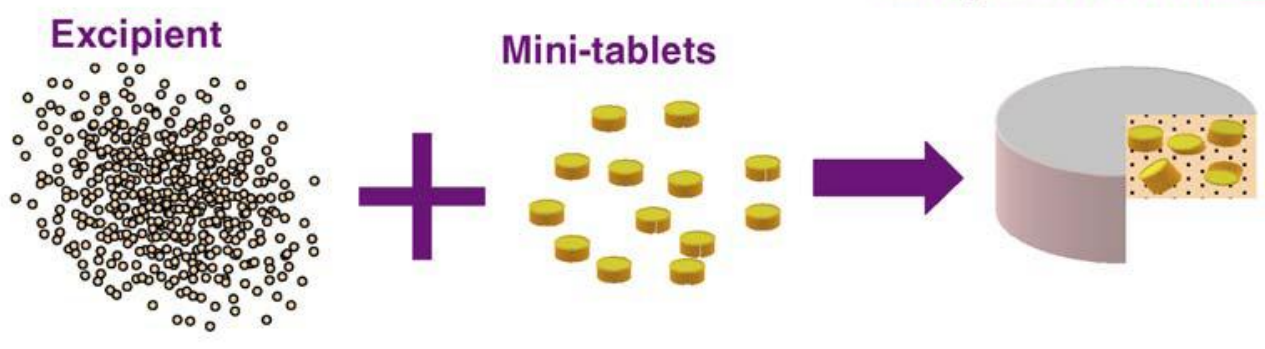

(b)

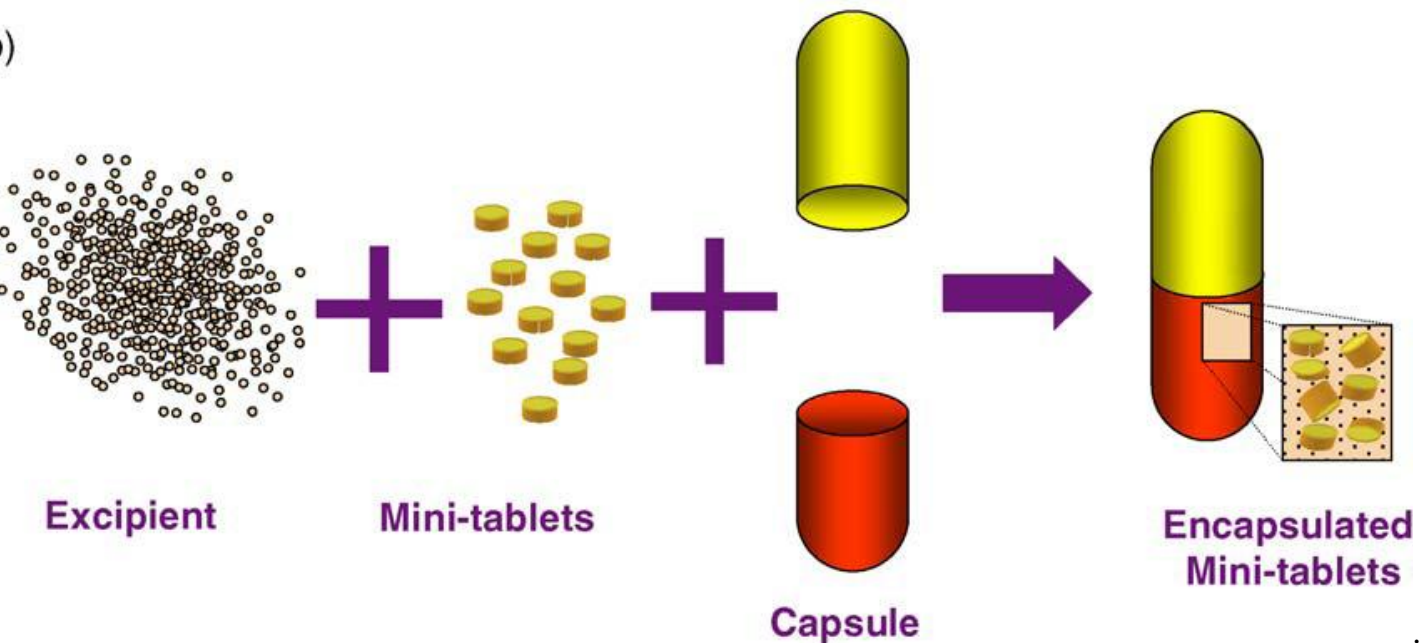

Figure-1 Mini-Tablets delivered as a) Tablets or b) capsules

In order to investigate the mode of release from delayed release tablet, the release data were analyzed using following mathematical models: Zero-order kinetic (Equation 1); First- order kinetic (equation2); Higuchi equation (square root of time equation, equation 3) ${ }^{[7]}$; and Peppas equation (equation 4) ${ }^{[8]}$.

Eq.1. $\mathrm{Q}=\mathrm{k} 0 \mathrm{t}$

Eq.2. $\ln (100-\mathrm{Q})=\ln (\mathrm{Q} 0)-\mathrm{k} 1 \mathrm{t}$

Eq.3. $\mathrm{Q}=\mathrm{kH} \mathrm{t} 1 / 2$

Eq.4. $\log (\mathrm{Q} / 100)=\mathrm{kptn}$

In equations $\mathrm{Q}$, the percent of drug released is at time $\mathrm{t}, \mathrm{Q} 0$, the percent of drug remaining to release and $\mathrm{k} 0, \mathrm{k} 1$ and $\mathrm{kH}$ are the coefficients of the equations. Kp is constant incorporating structural and geometric characteristics of the release device, and $n$ is the Release exponent indicative of the mechanism of release.

\section{MATERIALS:}

\section{MATERIALS AND METHODS}

The following chemicals were obtained from commercial suppliers and used as received: Clopidogrel bisulphate (Orchid chemicals and pharmaceuticals ltd., Chennai) Tartaric acid (Merck, USA), Opadry AMB white 80 W68912 (colorcon, India), Silicon dioxide (syloid 244 FP)(Grace division, USA), Microcrystalline cellulose (Avicel PH 112) (FMC ,USA), Mannitol (pearlitol SD 200)(Roquette pharma, france), Hydrogenated castor oil(Kolwax HCO)(BASF, India), (Talc (Luzenac, Italy), pregealtinised starch (Starch 1500, Dow, USA), Ethyl cellulose (Ethocel 7cps)(Dow chemicals, USA), Hypromellose phthalate HP 50(Shin etsu, Japan), Hpromellose (E5LV, Dow chemical, USA), size '1'Hard gelatin capsules (ACG capsules, India), Isopropyl alcohol and methylene chloride was procured from RFCL Limited., New Delhi, India. All chemicals were reagent grade or higher. Digital weighing balance (C-220) (make: Saritorious), Mechanical sifter with the screens of ASTM 40\# \& ASTM 60\#, Octagonal blender 4L (Sams tech, India), Fluid bed processor (GPCG 1.1), (Make: Pam machineries), 16 station rotary compression machine (Cadmach, India), conventional coating pan(a Remi mechanical propellant stirrer (RA124) (make:Remi), Manual capsule filling machine (MAC 300) (make: Pam machineries), Tray drier (make : Ganson engg), double beam UV Visible spectrophotometer (make: schimadzu), Dissolution test apparatus (Electrolab), 


\section{METHODS:}

a. Preparation of Extended release Mini-Tablets ${ }^{[9],}$

Formulation of clopidogrel extended mini-tablets mini tablets involves 4 stages

a) Stage - I : Blending, granulation

b) Stage - II : Compression

c) Stage - III : Film coating

d) Stage - IV : Extended release coating

Stage -I Blending, granulation :Clopidogrel, tartaric acid, Mannitol, microcrystalline cellulose are co -sifted through ASTM 40\#. Hypromellose E5 LV is dissolved in methylene chloride and isopropyl alcohol. The above sifted materials are loaded in fluid bed processor GPCG 1.1, and granulated using Hypromellose E5LV solution, the granules are passed through ASTM 30\# .Talc and silicon dioxide are sifted through ASTM 60\#, loaded in to blender and mixed for 15 minutes, at 15 RPM. Hydrogenated castor oil is sifted through ASTM 60\#, loaded into the blender and mixed for 5 minutes. Each formula was having the batch size of 4000 units.

Stage -II Compression: The lubricated blend was compressed using $2.5 \mathrm{~mm}$ multi-tip punch with the target weight of $20 \mathrm{mg} / \mathrm{unit}$ and 8 units/unit dose. The compressed mini-tablets were evaluated for hardness, thickness and disintegration time. The lot size for coating was 4000 units.

Stage-III: Barrier coating: Opadry AMB white 80W50612 suspended in Isopropyl alcohol and methylene chloride admixture under stirring. Stirring for continued for 30 minutes. The resultant suspension was coated on compressed mini-tablets with different percentage weight gain by using conventional coating pan. During the preparation of coating solution the $10 \%$ of excess was prepared to recover the loss during practical work. The solid content of barrier coating suspension was $7 \% \mathrm{w} / \mathrm{w}$

Stage-IV: Controlled Release coating: Hypromellose phthalate, Ethyl cellulose, Hypromellose are suspended in isopropyl alcohol, followed by methylene chloride is added to above solution under stirring, to get clear solution. Talc and triacetin is added to the above solution and mixed for 10minutes. The resultant suspension was coated on barrier coated mini-tablets with different percentage weight gain by using conventional coating pan. During the preparation of coating solution the $10 \%$ of excess was prepared to recover the loss during practical work. The solid content of extended release coating suspension was $5 \% \mathrm{w} / \mathrm{w}$. (The coating pan was rotated at a speed $28 \mathrm{rpm}$, spray rate $10 \mathrm{gm} / \mathrm{min}$, inlet air temperature is around $40-45^{\circ} \mathrm{C}$ and Exhaust air temperature is around $30-35^{\circ} \mathrm{C}$ ). A coating load of $10 \%$ was used to test the effect of the various ratios of Ethyl cellulose, Hypromellose phthalate and Hypromellose.

Encapsulation: The coated mini-tablets were filled in to size "0" hard gelatin capsules, and evaluated for assay and dissolution.

Table-1Composition of Clopidogrel Extended Release Mini-tablets

\begin{tabular}{|c|c|c|c|c|c|c|c|c|c|}
\hline $\begin{array}{c}\text { S.N } \\
\mathbf{0}\end{array}$ & Ingredients & F31 & F32 & F33 & F34 & F35 & F36 & F37 & F38 \\
\hline & $\begin{array}{c}\text { Ratio of- Ethocel : } \\
\text { Hypromellose phthalate: } \\
\text { HPMC }\end{array}$ & $\begin{array}{l}\text { 50:40: } \\
10\end{array}$ & $\begin{array}{c}\text { 60:30:1 } \\
0\end{array}$ & 70:20:10 & $\begin{array}{l}\text { 50:45: } \\
\quad 5\end{array}$ & $\begin{array}{l}\text { 60:35: } \\
5\end{array}$ & $\begin{array}{l}70: 25: \\
5\end{array}$ & $\begin{array}{l}\text { 60:25: } \\
15\end{array}$ & $\begin{array}{l}50: 35: \\
15\end{array}$ \\
\hline 1 & Clopidogrel Bisulphate & 97.875 & 97.875 & 97.875 & 97.875 & 97.875 & 97.875 & 97.875 & 97.875 \\
\hline 2 & Tartaric acid & 25 & 25 & 25 & 25 & 25 & 25 & 25 & 25 \\
\hline 3 & Mannitol & 25.125 & 25.125 & 25.125 & 25.125 & 25.125 & 25.125 & 25.125 & 25.125 \\
\hline 4 & $\begin{array}{l}\text { Microcrystalline cellulose } \\
\text { (Avicel PH112) }\end{array}$ & 75 & 75 & 75 & 75 & 75 & 75 & 75 & 75 \\
\hline 5 & Hypromellose E5LV & 5 & 5 & 5 & 5 & 5 & 5 & 5 & 5 \\
\hline 6 & Isopropyl alcohol & qs & qs & qs & qs & qs & qs & qs & qs \\
\hline
\end{tabular}


A Novel Approach To Extended Release Clopidogrel...

\begin{tabular}{|c|c|c|c|c|c|c|c|c|c|}
\hline 7 & Methylene chloride & qs & qs & qs & qs & qs & qs & qs & qs \\
\hline 8 & $\begin{array}{l}\text { Silicon dioxide (Syloid } \\
\text { 244FP) }\end{array}$ & 3 & 3 & 3 & 3 & 3 & 3 & 3 & 3 \\
\hline 9 & Talc & 3 & 3 & 3 & 3 & 3 & 3 & 3 & 3 \\
\hline 10 & Hydrogenated castor oil & 6 & 6 & 6 & 6 & 6 & 6 & 6 & 6 \\
\hline & Sub total & 240 & 240 & 240 & 240 & 240 & 240 & 240 & 240 \\
\hline \multicolumn{10}{|c|}{ Barrier coating } \\
\hline 1 & Opadry AMB white & 14.4 & 14.4 & 14.4 & 14.4 & 14.4 & 14.4 & 14.4 & 14.4 \\
\hline 2 & Methylene chloride & qs & qs & qs & qs & qs & qs & qs & qs \\
\hline 3 & Isopropyl alcohol & qs & qs & qs & qs & qs & qs & qs & qs \\
\hline & Total & 254.4 & 254.4 & 254.4 & 254.4 & 254.4 & 254.4 & 254.4 & 254.4 \\
\hline \multicolumn{10}{|c|}{ Extended Release coating } \\
\hline 1 & Ethyl cellulose $7 \mathrm{cps}$ & 10.60 & 12.72 & 14.84 & 10.60 & 12.72 & 14.84 & 12.72 & 10.60 \\
\hline 2 & $\begin{array}{l}\text { Hypromellose phthalate } \\
\text { HP50 }\end{array}$ & 8.48 & 6.36 & 4.24 & 9.54 & 7.42 & 5.3 & 5.3 & 7.42 \\
\hline 3 & Hypromellose 5cps & 2.12 & 2.12 & 2.12 & 1.06 & 1.06 & 1.06 & 3.18 & 3.18 \\
\hline 4 & Triacetin & 2.12 & 2.12 & 2.12 & 2.12 & 2.12 & 2.12 & 2.12 & 2.12 \\
\hline 5 & Talc & 2.12 & 2.12 & 2.12 & 2.12 & 2.12 & 2.12 & 2.12 & 2.12 \\
\hline 6 & Isopropyl alcohol & qs & qs & qs & qs & qs & qs & qs & qs \\
\hline 7 & Methylene chloride & qs & qs & qs & qs & qs & qs & qs & qs \\
\hline & Total & 279.84 & 279.84 & 279.84 & 279.84 & 279.84 & 279.84 & 279.84 & 279.84 \\
\hline
\end{tabular}

Table-2: In-Process parameters at various steps:

\begin{tabular}{|l|c|c|c|}
\hline Parameters & Compression & Barrier Coating & $\begin{array}{c}\text { Extended Release } \\
\text { coating }\end{array}$ \\
\hline Description & $\begin{array}{c}\text { white to off white circular } \\
\text { biconvex tablets }\end{array}$ & $\begin{array}{c}\text { white to off white circular } \\
\text { biconvex tablets }\end{array}$ & $\begin{array}{c}\text { white to off white circular } \\
\text { biconvex tablets }\end{array}$ \\
\hline Weight variation & $20 \mathrm{mg} \pm 10 \%$ & $21.2 \mathrm{mg} \pm 10 \%$ & $23.32 \mathrm{mg} \pm 10 \%$ \\
\hline Hardness & $4-10 \mathrm{~N}$ & $7-15 \mathrm{~N}$ & $20-30 \mathrm{~N}$ \\
\hline Thickness & $3.1-3.5 \mathrm{~mm}$ & $3.1-3.5 \mathrm{~mm}$ & $3.2-3.6 \mathrm{~mm}$ \\
\hline
\end{tabular}

Stability studies ${ }^{[10,11]}$ three

The optimized formulations were evaluated for accelerated stability studies at $40^{\circ} \mathrm{C}$ and $75 \% \mathrm{RH}$ for 


\section{Evaluation of clopidogrel film coated mini tablets}

Uniformity of Tablet Weight Test ${ }^{[12]}$ : Ten capsules from the batch were randomly selected, individual weight of the selected representative was determined using a digital electronic balance. The average tablet weight and the standard deviation from the mean were calculated.

Capsule disintegration Test ${ }^{[12]}$ : Six capsules randomly selected were introduced into the six baskets of the disintegration testing apparatus (Electrolab, India). The disintegrating medium was de ionized water maintained at $37^{\circ} \mathrm{c}+1.0^{\circ} \mathrm{c}$. The time taken for each capsule to disintegrate to break up into a smaller units and passes through the screen mesh orifices at the bottom of the basket was recorded.

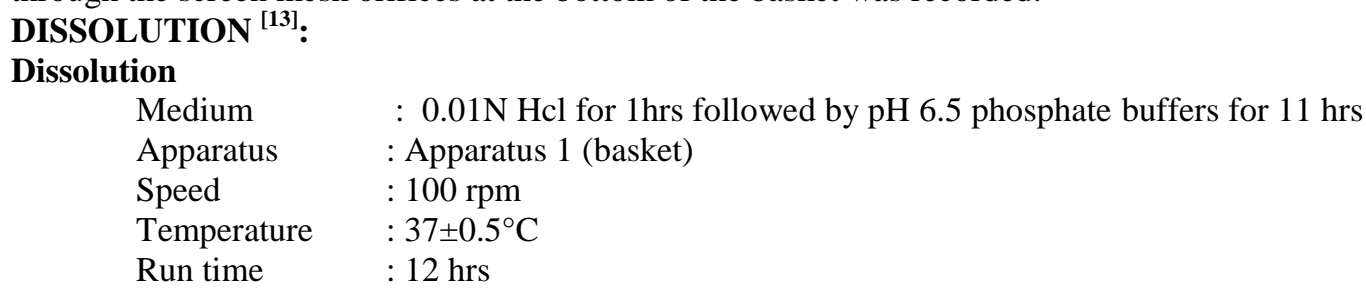

Procedure : $1000 \mathrm{ml}$ of $0.01 \mathrm{~N} \mathrm{HCl}$ was placed in the vessel and the USP standard dissolution apparatus -1 (basket method) was assembled. The medium was allowed to equilibrate to temperature of $37 \pm 0.5^{\circ} \mathrm{C}$. capsules were placed in basket and were covered. The apparatus was operated for 1 hours at $100 \mathrm{rpm}$. At definite time intervals $5 \mathrm{ml}$ of the receptor fluid was withdrawn, filtered, suitable dilutions were done with $0.01 \mathrm{~N} \mathrm{HCl}$ and analyzed spectrophotometrically at $240 \mathrm{~nm}$ using Elico UV-Visible spectrophotometer. After $1 \mathrm{hr}$ they are transferred in to baskets containing 1000ml of Phosphate buffer $\mathrm{pH} 6.5$ and the apparatus was operated till $12 \mathrm{hrs}$ at 100rpm. Similarly at definite intervals $5 \mathrm{ml}$ of the receptor fluid was withdrawn, filtered, suitable dilutions were done with $0.01 \mathrm{~N} \mathrm{HCl}$ and analyzed spectrophotometrically at $240 \mathrm{~nm}$ using Elico UV-Visible spectrophotometer.

Assay ${ }^{[14]}$ :

Weigh and finely powder the content of not fewer than 10 Capsules. Transfer an accurately weighed portion of the powder, equivalent to about $75 \mathrm{mg}$ of clopidogrel (base), to a $100-\mathrm{mL}$ volumetric flask, and add $50 \mathrm{~mL}$ of methanol. Sonicate for 5 minutes, and stir for 30 minutes. Dilute with methanol to volume, and mix. Transfer $5.0 \mathrm{~mL}$ of this solution to the flask, dilute with methanol to $50.0 \mathrm{~mL}$, and mix. Pass a portion of this solution through a filter having a $0.45-\mu \mathrm{m}$ or finer porosity, and measure the absorbance with the use the filtrate after discarding the first $5 \mathrm{~mL}$. Determine the amount of clopidogrel by employing UV absorption at the wavelength of maximum absorbance at about $270 \mathrm{~nm}$

\section{Water content ${ }^{[15]}$ :}

Water content of capsule was evaluated by direct titrimetric method, as per USP 34-NF 29, Physical Tests / $/ 921\rangle$ Water Determination, and the values are presented in Table-4

\section{Drug Release Kinetics:}

To analyze the in vitro release data various kinetic models were used to describe the release kinetics. The zero order rate Eq. (1) describes the systems where the drug release rate is independent of its concentration (Hadjiioannou et al., 1993). The first order Eq. (2) describes the release from system where release rate is concentration dependent (Bourne, 2002). Higuchi (1963) described the release of drugs from insoluble matrix as a square root of time dependent process based on Fickian diffusion Eq. (3). The Hixson-Crowell cube root law Eq. (4) describes the release from systems where there is a change in

surface area and diameter of particles or tablets (Hixson and Crowell, 1931).

$\mathrm{C}=\mathrm{k} 0 \mathrm{t}(1)$

Where, $\mathrm{K}_{0}$ is zero-order rate constant expressed in units of concentration/time and $\mathrm{t}$ is the time.

$\log \mathrm{C}=\log \mathrm{Co}-\mathrm{kt} / 2.303$ (2)

Where, $\mathrm{C} 0$ is the initial concentration of drug and $\mathrm{K}$ is first order constant and $\mathrm{t}$ is the time ${ }^{[16]}$ $\mathrm{Q}=\mathrm{Kt}^{1 / 2}(3)$

Where, $\mathrm{K}$ is the constant reflecting the design variables of the system. Hence drug release rate is proportional to the reciprocal of the square root of time. ${ }^{[7]}$

$\mathrm{Q}^{1 / 3}-\mathrm{Qt}^{1 / 3}=\mathrm{KHC} \mathrm{t}(4)$

Where, $\mathrm{Q}_{\mathrm{t}}$ is the amount of drug released in time $\mathrm{t}, \mathrm{Q}_{0}$ is the initial amount of the drug in tablet and $\mathrm{KHC}$ is the rate constant The following plots were made: cumulative \% drug release vs. time (zero order kinetic model); log cumulative of $\%$ drug remaining vs. time (first order kinetic model); cumulative $\%$ drug release vs. square root of time (Higuchi model) log cumulative \% drug release vs. log time (Korsmeyer model) . 


\section{RESULTS \& DISCUSSIONS:}

Physical Characterization of Clopidogrel Extended Release Mini-tablets filled in capsules:

Table 3: Physical Characterization of Clopidogrel mini-tablets filled in capsules

\begin{tabular}{|c|c|c|c|c|c|c|c|c|}
\hline Parameters & $\begin{array}{c}\text { Batch } \\
\text { Number }\end{array}$ & & & & & & & \\
\hline & F31 & F32 & F33 & F34 & F35 & F36 & F37 & F38 \\
\hline & \multicolumn{8}{|c|}{ Stage : Compression } \\
\hline $\begin{array}{l}\text { Uniformity of } \\
\text { tablet weight }\end{array}$ & $\begin{array}{c}20.2 \pm \\
0.08\end{array}$ & $\begin{array}{c}20.1 \pm \\
0.08\end{array}$ & $\begin{array}{c}20.2 \pm \\
0.23\end{array}$ & $\begin{array}{c}20.1 \pm \\
0.18 \\
\end{array}$ & $20.2 \pm 0.3$ & $\begin{array}{c}20.1 \pm \\
0.15 \\
\end{array}$ & $\begin{array}{c}20.4 \pm \\
0.24 \\
\end{array}$ & $\begin{array}{c}20.4 \pm \\
0.14 \\
\end{array}$ \\
\hline Hardness (N) & $5-6$ & $5-7$ & $6-8$ & $5-7$ & $5-7$ & $5-8$ & $5-8$ & $5-8$ \\
\hline Thickness (mm) & $3.2-3.3$ & $3.2-3.3$ & $3.2-3.3$ & 3.2-3.3 & $3.2-3.3$ & $3.2-3.3$ & $3.2-3.3$ & $3.2-3.3$ \\
\hline $\begin{array}{l}\text { Friability } \\
(\% \mathrm{w} / \mathrm{w})\end{array}$ & 0.12 & 0.13 & 0.12 & 0.12 & 0.12 & 0.12 & 0.12 & 0.13 \\
\hline \multirow[t]{2}{*}{ Description } & \multicolumn{8}{|c|}{ White to off white, circular biconvex tablets } \\
\hline & \multicolumn{8}{|c|}{ Stage : Barrier coating } \\
\hline $\begin{array}{l}\text { Uniformity of } \\
\text { tablet weight }\end{array}$ & $21.4 \pm 0.1$ & $\begin{array}{c}21.4 \pm \\
0.08\end{array}$ & $\begin{array}{c}21.4 \pm \\
0.09\end{array}$ & $\begin{array}{c}21.4 \pm \\
0.08 \\
\end{array}$ & $\begin{array}{c}21.2 \pm \\
0.05\end{array}$ & $\begin{array}{c}21.3 \pm \\
0.05\end{array}$ & $\begin{array}{c}21.4 \pm \\
0.12 \\
\end{array}$ & $\begin{array}{c}21.4 \pm \\
0.05\end{array}$ \\
\hline Hardness & $11-14$ & $11-14$ & $12-14$ & $11-13$ & $11-13$ & $11-13$ & $11-14$ & $11-14$ \\
\hline Thickness & $3.3-3.4$ & $3.3-3.4$ & $3.3-3.4$ & $3.3-3.4$ & $3.3-3.4$ & $3.3-3.4$ & $3.3-3.4$ & $3.3-3.4$ \\
\hline Description & \multicolumn{8}{|c|}{ White to off white, circular biconvex film coated tablets } \\
\hline & \multicolumn{8}{|c|}{$\begin{array}{l}\text { Stage : Functional coating } \\
\end{array}$} \\
\hline $\begin{array}{l}\text { Uniformity of } \\
\text { tablet weight }\end{array}$ & $\begin{array}{c}23.4 \pm \\
0.05 \\
\end{array}$ & $\begin{array}{c}23.4 \pm \\
0.10 \\
\end{array}$ & $\begin{array}{c}23.5 \pm \\
0.08 \\
\end{array}$ & $\begin{array}{c}23.4 \pm \\
0.08 \\
\end{array}$ & $\begin{array}{c}23.4 \pm \\
0.06 \\
\end{array}$ & $\begin{array}{c}23.4 \pm \\
0.05 \\
\end{array}$ & $\begin{array}{c}23.5 \pm \\
0.05 \\
\end{array}$ & $\begin{array}{c}23.4 \pm \\
0.06 \\
\end{array}$ \\
\hline Hardness & $22-24$ & $22-26$ & $22-24$ & $21-25$ & $22-27$ & $22-24$ & $22-24$ & $22-25$ \\
\hline Thickness & $3.4-3.5$ & $3.4-3.5$ & $3.4-3.5$ & $3.4-3.5$ & $3.4-3.5$ & $3.4-3.5$ & $3.4-3.5$ & $3.4-3.5$ \\
\hline Description & \multicolumn{8}{|c|}{ White to off white, circular biconvex film coated tablets } \\
\hline & \multicolumn{8}{|c|}{ Stage : Capsules } \\
\hline $\begin{array}{l}\text { Number of mini- } \\
\text { tablets per } \\
\text { capsule }\end{array}$ & 12 & 12 & 12 & 12 & 12 & 12 & 12 & 12 \\
\hline $\begin{array}{l}\text { Uniformity of } \\
\text { capsule weight }\end{array}$ & $\begin{array}{c}375.2 \pm \\
0.98\end{array}$ & $\begin{array}{c}375.5 \pm \\
1.05\end{array}$ & $\begin{array}{c}374.0 \pm \\
1.55\end{array}$ & $\begin{array}{c}375.2 \pm \\
0.75\end{array}$ & $\begin{array}{c}375.3 \pm \\
1.51\end{array}$ & $\begin{array}{c}374.7 \pm \\
0.52\end{array}$ & $\begin{array}{c}374.8 \pm \\
0.75\end{array}$ & $\begin{array}{c}375.5 \pm \\
0.84\end{array}$ \\
\hline $\begin{array}{l}\text { Disintegration } \\
\text { time }\end{array}$ & 4-6 min & $4-6 \min$ & $4-6 \min$ & 4-6 min & 4-6 min & 4-6 min & 4-6 min & 4-6 min \\
\hline Description & \multicolumn{8}{|c|}{ White to off white, circular biconvex film coated tablets filled in white opaque hard gelatin capsules } \\
\hline
\end{tabular}


Chemical Characterization of Clopidogrel Extended Release Mini-tablets filled in capsules:

Table 4: Chemical Characterization of Clopidogrel Extended Release mini-tablets filled in capsules

\begin{tabular}{|c|c|c|c|c|c|c|c|c|}
\hline Parameters & \multicolumn{8}{|c|}{ Batch Number } \\
\hline & F31 & F32 & F33 & F34 & F35 & F36 & F37 & F38 \\
\hline Assay & $\begin{array}{c}100.7 \pm \\
0.81 \\
\end{array}$ & $\begin{array}{c}99.9 \pm \\
0.35 \\
\end{array}$ & $\begin{array}{c}100.5 \pm \\
0.06\end{array}$ & $\begin{array}{c}100.3 \pm \\
0.42\end{array}$ & $\begin{array}{c}100.3 \pm \\
0.80\end{array}$ & $\begin{array}{c}100.7 \pm \\
0.40\end{array}$ & $\begin{array}{c}100.8 \pm \\
0.30\end{array}$ & $\begin{array}{c}100.5 \pm \\
0.52\end{array}$ \\
\hline $\begin{array}{l}\text { Water (by KF) } \\
(\% \text { w/w })\end{array}$ & 1.25 & 1.42 & 1.5 & 1.52 & 1.54 & 1.61 & 1.35 & 1.58 \\
\hline \multicolumn{9}{|c|}{ Dissolution in 0.01N HCl, 900ml, 100 RPM, USP-I } \\
\hline $30 \mathrm{~min}$ & $\begin{array}{c}10.1 \pm \\
0.25\end{array}$ & $\begin{array}{c}9.6 \pm \\
0.10\end{array}$ & $\begin{array}{c}10.3 \pm \\
0.21\end{array}$ & $\begin{array}{c}4.6 \pm \\
0.15\end{array}$ & $\begin{array}{l}4.5 \pm \\
0.23\end{array}$ & $\begin{array}{l}3.9 \pm \\
0.35\end{array}$ & $\begin{array}{c}19.8 \pm \\
1.18\end{array}$ & $\begin{array}{c}20.3 \pm \\
0.20\end{array}$ \\
\hline 1hr & $\begin{array}{c}23.3 \pm \\
0.44 \\
\end{array}$ & $\begin{array}{c}24.4 \pm \\
0.17 \\
\end{array}$ & $\begin{array}{c}24.6 \pm \\
0.20 \\
\end{array}$ & $\begin{array}{c}20.5 \pm \\
0.55 \\
\end{array}$ & $\begin{array}{c}20.3 \pm \\
0.17 \\
\end{array}$ & $\begin{array}{c}21.5 \pm \\
0.45 \\
\end{array}$ & $\begin{array}{c}31.8 \pm \\
0.30 \\
\end{array}$ & $\begin{array}{c}34.9 \pm \\
0.38 \\
\end{array}$ \\
\hline \multicolumn{9}{|c|}{ pH 6.5 Phosphate buffer, 900ml, USP-I, 100RPM } \\
\hline $2 \mathrm{hrs}$ & $\begin{array}{c}61.7 \pm \\
0.67\end{array}$ & $\begin{array}{c}43.4 \pm \\
0.21\end{array}$ & $\begin{array}{c}38.1 \pm \\
0.25\end{array}$ & $\begin{array}{c}58.4 \pm \\
0.21\end{array}$ & $\begin{array}{c}41.8 \pm \\
0.65\end{array}$ & $\begin{array}{c}36.0 \pm \\
0.47\end{array}$ & $\begin{array}{c}46.2 \pm \\
0.35\end{array}$ & $\begin{array}{c}75.6 \pm \\
0.46\end{array}$ \\
\hline $4 \mathrm{hrs}$ & $\begin{array}{c}78.9 \pm \\
0.38\end{array}$ & $\begin{array}{c}56.8 \pm \\
0.06\end{array}$ & $\begin{array}{c}49.7 \pm \\
0.69\end{array}$ & $\begin{array}{l}75.6 \pm \\
0.25\end{array}$ & $\begin{array}{c}51.4 \pm \\
0.21\end{array}$ & $\begin{array}{l}45.6 \pm \\
0.25\end{array}$ & $\begin{array}{c}62.1 \pm \\
0.53\end{array}$ & $\begin{array}{c}82.4 \pm \\
0.26\end{array}$ \\
\hline $6 \mathrm{hrs}$ & $\begin{array}{c}85.2 \pm \\
0.76\end{array}$ & $\begin{array}{c}70.1 \pm \\
0.06\end{array}$ & $\begin{array}{c}60.7 \pm \\
0.36\end{array}$ & $\begin{array}{c}82.3 \pm \\
0.20\end{array}$ & $\begin{array}{c}65.2 \pm \\
0.06\end{array}$ & $\begin{array}{c}57.8 \pm \\
0.30\end{array}$ & $\begin{array}{c}76.2 \pm \\
0.36\end{array}$ & $\begin{array}{c}86.3 \pm \\
0.15\end{array}$ \\
\hline $8 \mathrm{hrs}$ & $\begin{array}{l}89.1 \pm \\
0.35 \\
\end{array}$ & $\begin{array}{l}75.4 \pm \\
0.15 \\
\end{array}$ & $\begin{array}{c}65.1 \pm \\
0.30\end{array}$ & $\begin{array}{c}86.5 \pm \\
0.06\end{array}$ & $\begin{array}{l}70.4 \pm \\
0.17 \\
\end{array}$ & $\begin{array}{c}65.1 \pm \\
0.30\end{array}$ & $\begin{array}{c}89.8 \pm \\
0.31 \\
\end{array}$ & $\begin{array}{c}88.4 \pm \\
0.35\end{array}$ \\
\hline $12 \mathrm{hrs}$ & $\begin{array}{c}92.4 \pm \\
0.12\end{array}$ & $\begin{array}{c}90.0 \pm \\
0.12\end{array}$ & $\begin{array}{c}75.8 \pm \\
0.15\end{array}$ & $\begin{array}{c}90.1 \pm \\
0.20\end{array}$ & $\begin{array}{c}85.9 \pm \\
0.59\end{array}$ & $\begin{array}{c}70.2 \pm \\
0.06\end{array}$ & $\begin{array}{c}99.1 \pm \\
0.20\end{array}$ & $\begin{array}{c}89.1 \pm \\
0.10\end{array}$ \\
\hline
\end{tabular}

Graph-1: Comparative dissolution profile of Clopidogrel extended release mini-tablets filed capsules in 0.01N HCl for $1 \mathrm{hr}$ followed by pH 6.5 Phosphate buffer for $11 \mathrm{hrs}$.

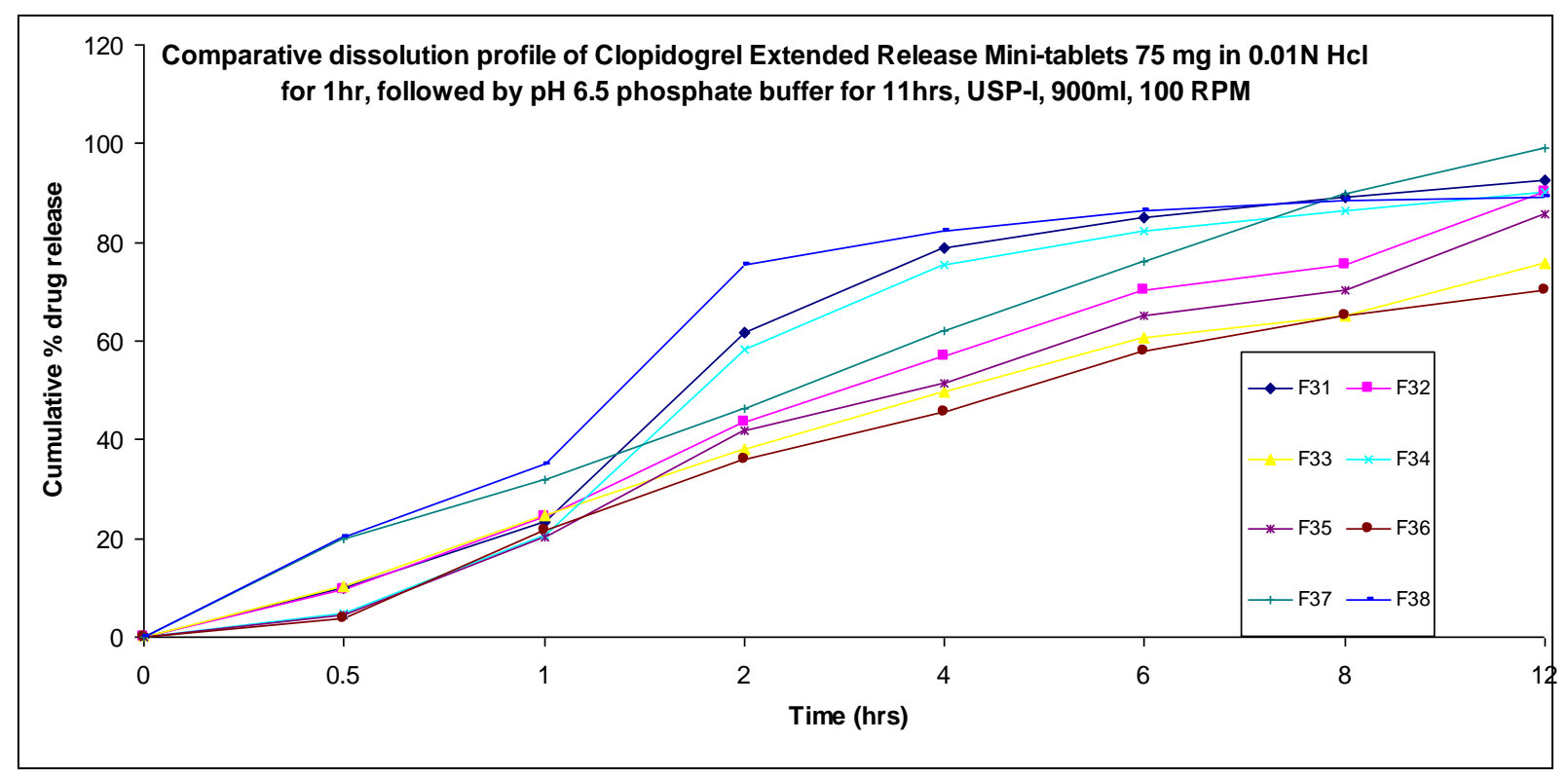

The data obtained from post-compression parameters for the core tablets, barrier coated tablets and extended release coated tablets filled in capsules such as thickness, hardness, friability, average weight, and drug content (Table 7). Friability is less than 1\%. All the formulations passed the weight variation test i.e., average percentage weight variation was found between $20.1 \pm 0.08$ to $23.5 \pm 0.08$. The drug content of mini- tablets filled in capsules was found to be 99.9 to $100.8 \%$. All the formulations passed the weight variation test. The weight variation was found to be within the pharmacopoeial limits of $\pm 10 \%$..In order to know the influence of ration of HPMC Phthalate, EC \& HPMC coating on mini-tablets a separate in-vitro dissolution testing was 
carried out for coated mini-tablets in capsules. With increase pore former of $15 \%$ HPMC, achieved initial release of $31.8 \%, 34.9 \%$ and the extent of drug release is also achieved respectively in formulation F37 \& F38.

\section{Kinetic release study:}

The kinetic modelling was evaluated for F37 \& F38. In order to determine the mechanism of drug release form the formulations, the in-vitro dissolution data was fitted to Zero order, First order, Higuchi plot and Korsemeyer-peppa's plot, the R2 value, slope and Y intercept was evaluated in each model and the values are presented table-5

Table-5: Pharmacokinetic modelling of clopidogrel extended release formulation

\begin{tabular}{|l|c|c|c|c|c|c|}
\hline \multicolumn{3}{|c|}{ Pharmacokinetic modelling of Clopidogrel Extended Release Mini-tablets ASC-C-F37 \& ASC-C-F38 } \\
\hline & \multicolumn{3}{|c|}{ ASC-C-F37 } & \multicolumn{3}{|c|}{ ASC-C-F38 } \\
\hline Zero order modelling & Slope & $\mathbf{R}^{\mathbf{2}}$ & Y intercept & Slope & $\mathbf{R}^{\mathbf{2}}$ & Y intercept \\
\hline First order modelling & 0.74 & 0.880 & 20.71 & 6.58 & 0.609 & 32.07 \\
\hline Higuchi modelling & 29.363 & 0.945 & 4.755 & 0.188 & 0.758 & 4.123 \\
\hline Koresmeyer peppas modelling & 0.506 & 0.987 & 1.422 & 24.217 & 0.733 & 11.271 \\
\hline
\end{tabular}

The formulation F37 in-vitro dissolution profile was plotted for zero order model, first order model, Higuchi plot and Korsemeyer-peppa's plot, the graphical presentation is given in graph 2 to 5

Graph-3: Zero order modelling of Clopidogrel extended release mini-tablets filled in capsules (ASC-C-F37)

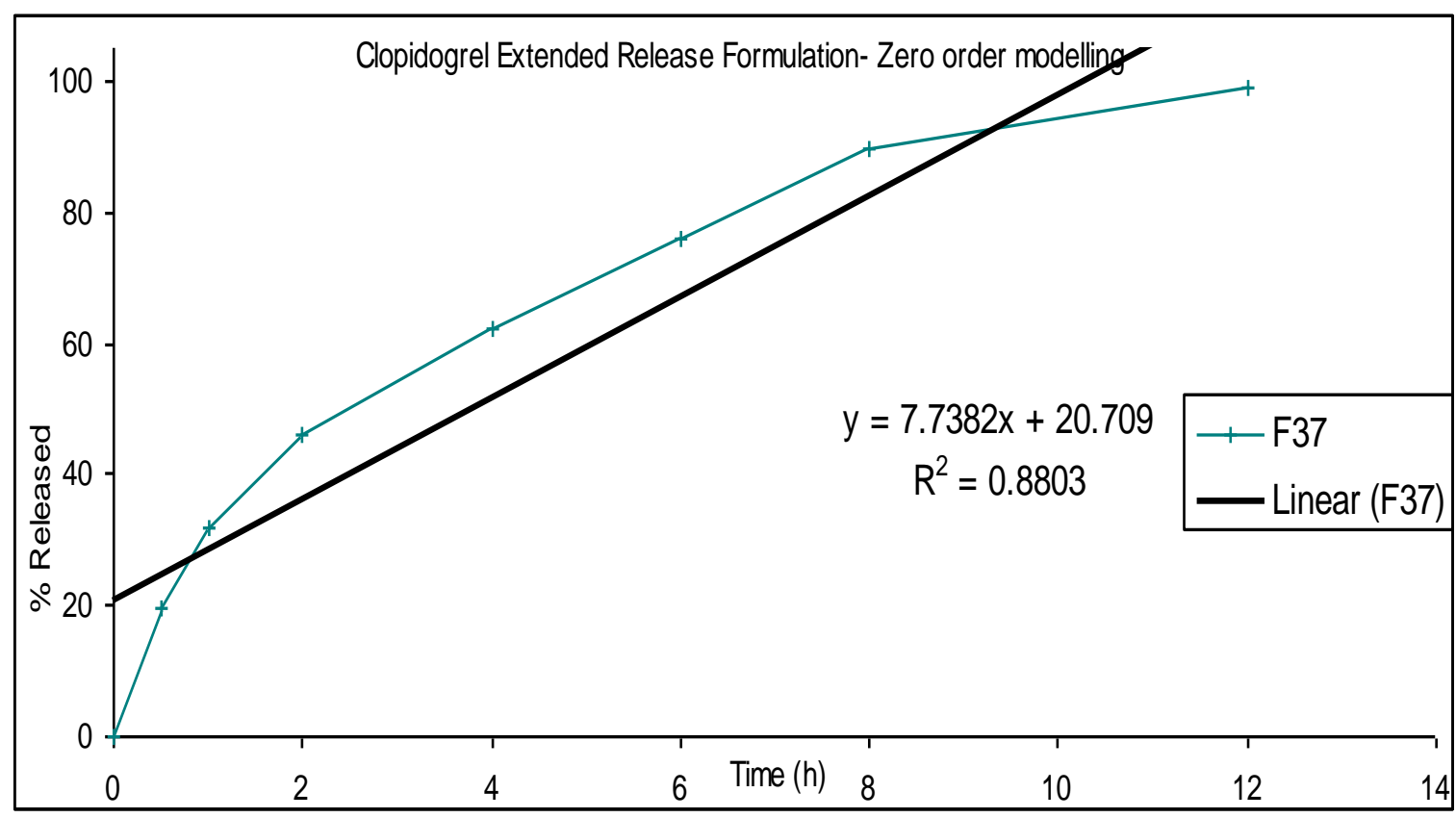

Graph-4: First order modelling of Clopidogrel extended release mini-tablets filled in capsules (ASC-CF37) 


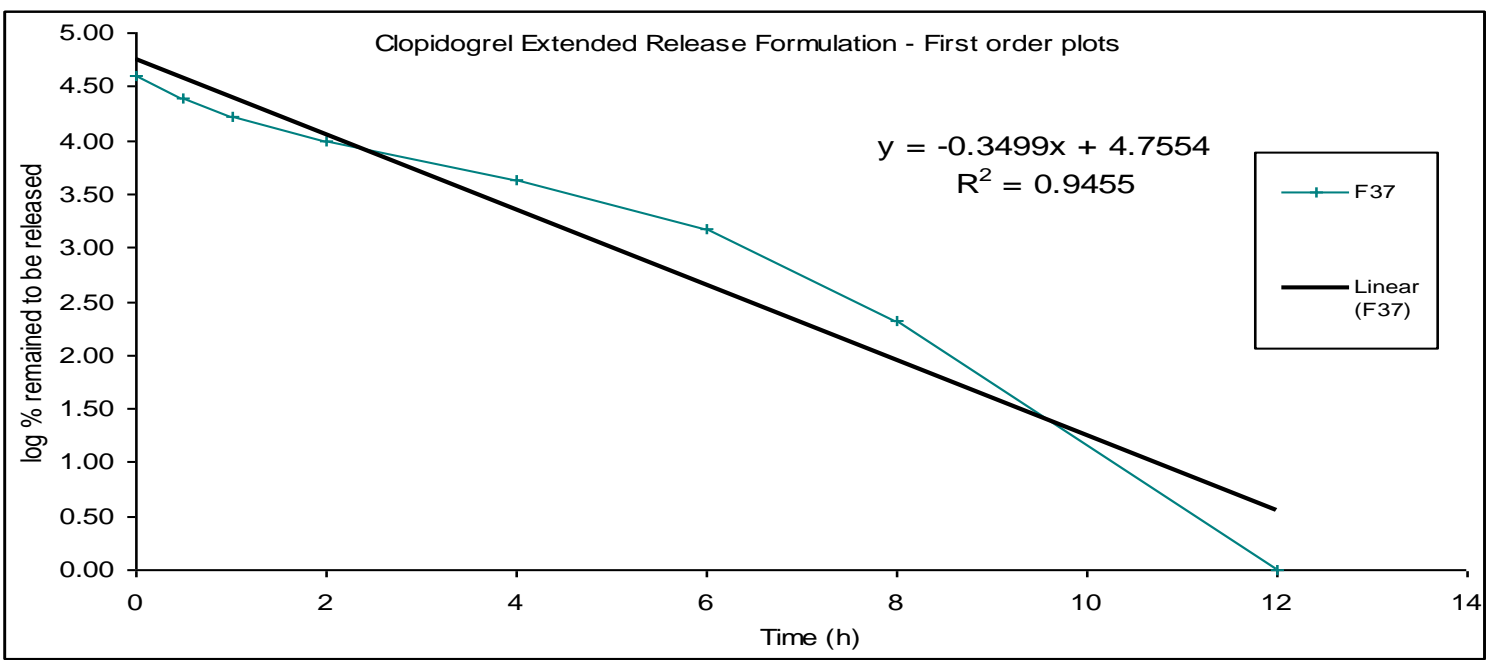

Graph-5: Higuchi modelling of Clopidogrel extended release mini-tablets filled in capsules (ASC-C-F37)

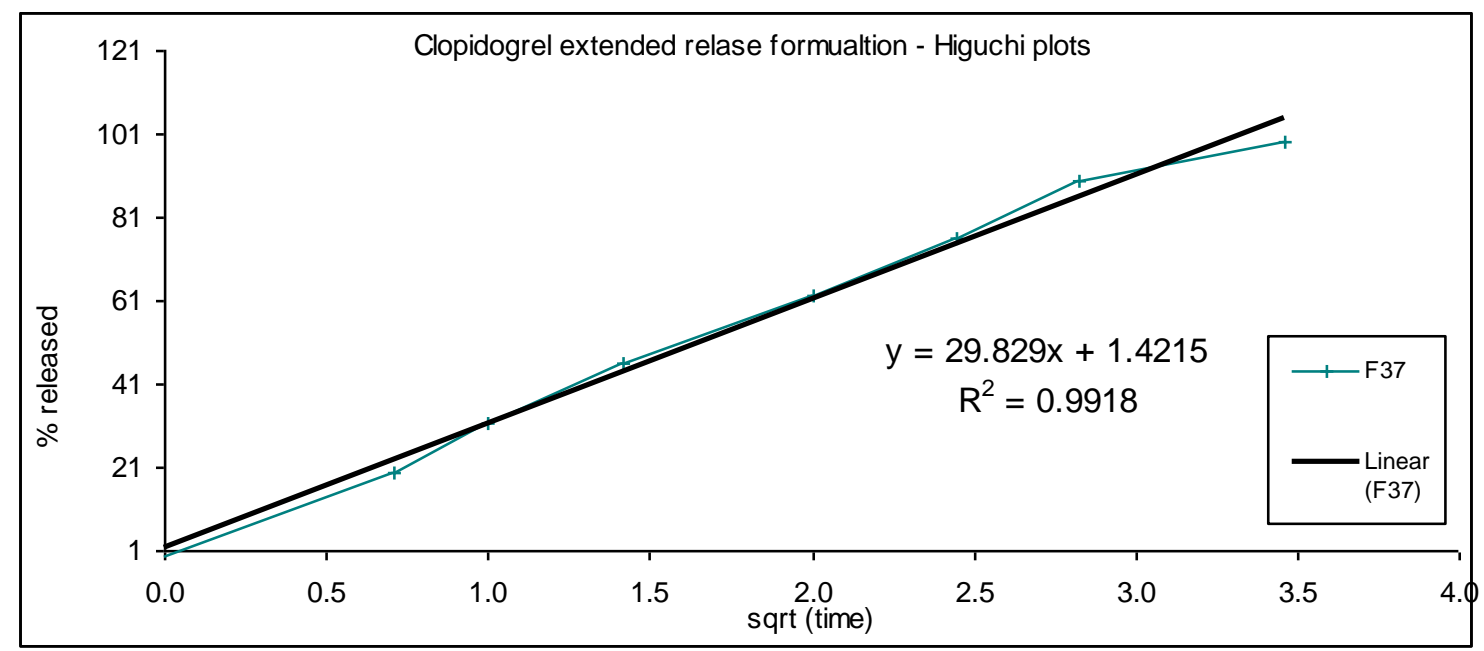

Graph-5: Koresmeyer peppas modelling of Clopidogrel extended release mini-tablets filled in capsules (ASC-C-F37)

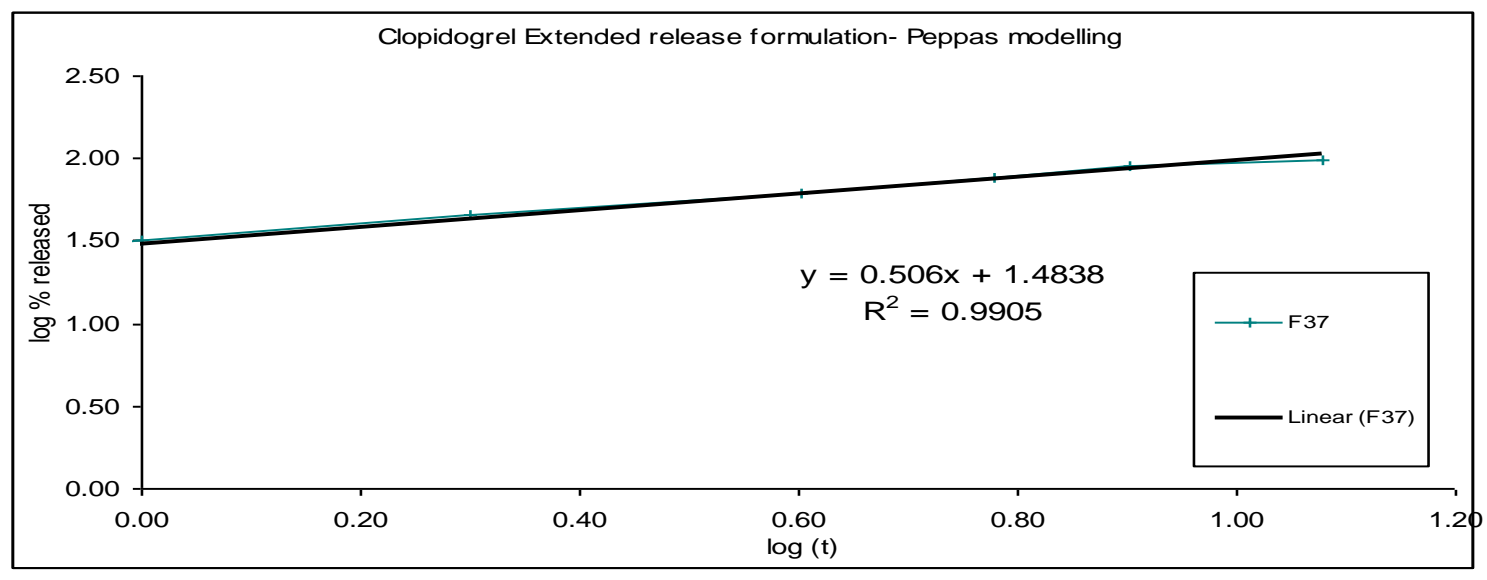


The results of $\mathrm{R}^{2}$ for zero and first order were obtained as 0.880 and 0.945 respectively. Based on that we have confirmed that the optimized formulation followed first- order release. To ascertain, the drug release mechanism the in-vitro release data were also subjected to Higuchi's diffusion plots and Peppas plots and the $\mathrm{R}^{2}$ values was found to be 0.987 and 0.99 .Higuchi plot and Peppas plots were nearer to one in all the cases suggesting that drug released by diffusion mechanism.

\section{Accelerated stability study of Clopidogrel min-tablets filled in capsules:}

The filled capsules are packed in HDPE container with 30's count, loaded in accelerated stability condition. Initial and 3M accelerated stability samples of the filled capsules were evaluated for Description, Assay, water content and dissolution. The results are tabulated in Table- 8

Table 6: Assay, Water by KF and Dissolution: (Initial Vs 3M Accelerated condition)

\begin{tabular}{|c|c|c|c|c|}
\hline \multicolumn{5}{|c|}{ Accelerated Stability data of Clopidogrel extended release Mini-tablets filled in capsules } \\
\hline \multirow{2}{*}{\multicolumn{2}{|c|}{$\begin{array}{l}\text { Batch Number:ASC-C-F37 } \\
\text { Parameters }\end{array}$}} & \multicolumn{3}{|c|}{ Pack: HDPE bottle with 30's count } \\
\hline & & Specification & Initial & $3 \mathrm{M} 40 / 75$ \\
\hline \multicolumn{2}{|l|}{ Description } & $\begin{array}{l}\text { white to off-white } \\
\text { colored mini tablets } \\
\text { filled in white opaque } \\
\text { hard gelatin capsule }\end{array}$ & $\begin{array}{l}\text { white to off-white } \\
\text { colored mini tablets } \\
\text { filled in white opaque } \\
\text { hard gelatin capsule }\end{array}$ & $\begin{array}{l}\text { white to off- } \\
\text { white colored } \\
\text { mini tablets } \\
\text { filled in white } \\
\text { opaque hard } \\
\text { gelatin capsule }\end{array}$ \\
\hline \multicolumn{2}{|l|}{ Assay } & $\begin{array}{l}\text { NLT } 90 \% \text { and NMT } \\
110 \% \text { of label claim }\end{array}$ & $100.8 \pm 0.30$ & $99.9 \pm 0.2$ \\
\hline \multicolumn{2}{|c|}{ Water (by KF) (\% w/w) } & NMT 4 & 1.35 & 1.8 \\
\hline \multirow{4}{*}{ Dissolution } & $\begin{array}{c}\text { 0.01N HCl, 900ml, } \\
\text { USP-I, 100RPM }\end{array}$ & 1hr- NLT 25\% & $31.8 \pm 0.30$ & $30.7 \pm 0.5$ \\
\hline & \multirow{3}{*}{$\begin{array}{l}\text { pH } 6.5 \text { phosphate } \\
\text { buffer, } 900 \mathrm{ml}, \\
\text { USP-I, 100RPM }\end{array}$} & 2hrs- $40-60 \%$ & $46.2 \pm 0.35$ & $47.0 \pm 0.3$ \\
\hline & & 6 hrs- $60-80 \%$ & $76.2 \pm 0.36$ & $73.2 \pm 0.1$ \\
\hline & & 12 hrs-NLT $80 \%$ & $99.1 \pm 0.20$ & $98.5 \pm 0.1$ \\
\hline
\end{tabular}

*Listed value indicates mean value of results and Standard deviation (Where $n=3$ )

The above data reveals, that batch number F37 is not having significant difference from initial to $3 \mathrm{M}$ accelerated condition in Assay, dissolution, water content. The description remains unchanged form initial to accelerated condition.

\section{CONCLUSION}

An Extended release dosage form was successfully developed by filling 12 extended release minitablets into an empty hard gelatin capsule shell (size 0) which releases nearly the total dose for a period of 12 hours. The extended release coated mini-tablets in capsule releases nearly $31.8 \%$ in first hour, and the remaining dose was extended for a period of $12 \mathrm{hrs}$. The formulation coated with Ethyl cellulose, Hypromellose phthalate \& Hypromellose at the ratio of 60:25:15, with a buildup of 10\% showed a desired release profile. The release kinetics was studied for the formulation with various kinetic modeling. The data reveals formulation fits to first order kinetics and, dissolution is by diffusion mechanism. The formulation was evaluated at accelerated condition, and the data reveals, the product does not show any significant change at $3 \mathrm{M} 40 / 75$ in comparison to initial. 


\section{REFERENCES:}

[1] Plavix- Full prescribing information, approved by US Food and Drug administration, revised : December http:www.sanofi-aventis.com.Clark's Analysis of Drugs and Poisons, Pharmaceutical Press, 3 rd edition, $2004 ; 2,834$.

[2] Shaik Haroon Rasheed, Mulla Arief, Sandhya Vani P, Silpa Rani Gajavalli, Venkateshwarulu G, Vineela PAJ, Anjaneyulu N, and Naga Kishore R. Formulation and evaluation of sustained release tablets of Bupropion hydrochloride, Research Journal of Pharmaceutical Biological and Chemical Sciences. 2010; 1(4): 1017-1025.

[3] Pankaj Ramanbhai Patel, Sunilendu Bhushan Roy, Jay Shanthilal Kothari, Modified Release formulation, United states patent Application publication, US2010/0145053A1.

[4] Khosla R, Feely LC, Davis SS. Gastrointestinal transit of non-disintegrating tablets in fed subjects. Int J Pharm. 1989;53: 107-117.

[5] Lopes C.M., Souso Lobo J M, Pinto J F, Costa P. Compressed mini-tablets as a biphasic delivery system. Int. J. Pharm.,. 2006:323(1-2):93-100

[6] Higuchi T., Mechanism of sustained action medication: theoretical analysis of rate of release of solid in solid matrices. J Pharm Sci.1963; 52: 1145-1148.

[7] Korsmeyer RW, Gurny R, Doelker E, Buri P, Peppas NA. Mechanisms of solute release from porous polymers. Int J Pharm.1983; 15: 25-35.

[8] N.G. Raghavendra Rao, Mohd Abdul Hadi, Harsh A Panchal, A novel approach to sustained montelukast sodium release: Differentially coated mini-tablets in HPMC capsules, International Journal of PHARMACEUTICAL AND BIOMEDICAL RESEARCH, 2011, 2(2), 90-97

[9] Natalie, M.C., Clure. Stability studies in overview of ICH Guidelines for Drug Products. Matrix Pharmaceutical Inc., 1997; Available from URL: (http://www.mcclurenet.com).

[10] ICH, GUIDELINES Q1C, "Guidance for industry, stability testing of new dosage form" November 1996.http:/www.ich.org/about/organisation-ofich/coopgroup/asean/topics- underharmonisation/article/stabilitystudy.html

[11] Oyeniyi and Itiola OA, Pharmaceutical evaluation of direct compressible acetyl salicylic acid tablets containing sawdust microcrystalline cellulose , International journal of biology, pharmacy and applied $\quad$ science. April, 2012, 1(3): 195-203 Clopidogrel Bisulphate Tablets USP 32/NF 27, Page 1993

[12] Pravin B. Cholke*, Raihan Ahmed, S. Z. Chemate and K. R. Jadhav, Development and Validation of Spectrophotometric Method for Clopidogrel bisulfate in pure and in film coated tablet dosage form, Scholars Research Library, Archives of Applied Science Research, 2012, 4 (1):59-64

Physical Tests / 〈921〉 Water Determination, First Supplement to USP 34-NF 29

[13] Bourne DW. Pharmacokinetics In:Banker GS, Rhodes CT, eds. Modern Pharmaceutics. 4th ed, New York, NY:Marcel Dekker Inc, 2002:67-92. 